\title{
The Philosophy of positivism in economic science
}

\author{
A. P. Kyrychok \\ National Technical University of Ukraine "Igor Sikorsky Kyiv Polytechnic Institute", Kyiv, Ukraine \\ Corresponding author. E-mail: akyrychok@ukr.net
}

Paper received 05.03.18; Accepted for publication 15.03.18.

\section{https://doi.org/10.31174/SEND-HS2018-168VI27-13}

\begin{abstract}
The article deals with the results of economic research and question of their reliability. The author shows the issue of proof and verification economic research results, approaches to the verification of information. In particular, author pays attention to the principles of positivism and the possibilities of its application in economic science. The author focuses on the existence of two main areas, which are dominatenow by economic science: "economism" and "bibliometric". Since economic science is dominated by positions that can be identified as "economics" (the Anglo-American scientific and economic school), excessive attention is paid to the application of mathematical and statistical apparatus in research. The intensity of the use of mathematical methods identified as the quality and reliability of scientific research. There isanother tendency: due to the intensity of the use of bibliometric indicators for the evaluation of scientific results, bibliometrics has become a basic tool for verifying the reliability of scientific knowledge.
\end{abstract}

Keywords: philosophy positivism, verification of scientific researches, "economism", "biblottrism".

Introduction. As in every discipline, in economics it is important to determine the reliability and value of the results of scientific research. The problem lies in the fact that both in economic disciplines and in the humanities as a whole there is a great demand (both from the scientific community and from the side of the public and the state) for clear criteria for the truth of new knowledge. The numerous facts of inability of contemporary economic science to solve current problems, such as the inability to accurately predict the time of economic crises (moreover, to prevent them), despite the unprecedented large amount of accumulated economic information for a large community of scholars, has led to a general distrust of the results of a new economic research. Currently in general scientific discussion there is a tendency to "borrow" the criteria for the truth of scientific knowledge from other disciplines. The philosophical direction of positivism, as well as its trends ("second" positivism - empirio criticism, "new positivism," postpositivism) have developed a methodological and terminological apparatus, including numerous methods of proof and refutation. The successes of the natural sciences, "breakthrough" discoveries, increased the authority of their methodological basis and interest from the side of representatives of other disciplines. In economic terminology and methodology, attempts have been made to apply the principles of positivism, both with direct borrowing of the term, and by using only the methodology. However, in most cases, the use of the concept of "positivism" does not mean a critical attitude to the results of research or the application of other approaches of positive philosophy. On the contrary often hiding behind the authority of positivism adds more uncertainty to the scientific debate.

Therefore, the aim of the article is to reveal the peculiarities of the application of the principles and methodology of scientific positivism in economic science.

Scientific basis of research. The issues of methodology and methods of economic research have always been given much attention. Every science school has contributed to the development of a common methodology for economic science. If we say the actual work on this issue, then the contribution of such researchers should be noted. T. Efimenko and P. Leonenko [5] revealed the value of M.I. Tugan-Baranovsky's contribution to the develop- ment of the methodological apparatus of Ukrainian economic science. A large number of researchers developed issues of empirical research in the economy. In particular, A. Melnyk and N. Tsyschik [6] covered the issue of interpreting empirical data for households, S. Shumska analyzed the significance of empirical research in the study of economic dynamics. V. Heyets [3] disclosed the question of the political and economic principles of economic research as a part of humanitarian research in general. $\mathrm{M}$. Dovbenko [4] considers the question of the methodology of scientific research as part of the problem of further economic theory in general. V. Andriychuk [2] highlights the modern problems of the development of the methodology of humanities research in general, as well as the problems of the development of the methodological apparatus of economic science. In one way or another, all authors point at the problem of evaluating the value and reliability of the results in a situation where a large part of research has an interdisciplinary character, in general the number of scientific information is increasing, and the application of traditional approaches to assessing scientific knowledge is becoming more complicated.

In English economic literature, the question of the methodology of economic research is much broader. The number of works in this direction is quite numerous. For example, L. Boland [8] considers modeling as a universal method of research, which is widely used in economics. S. Drakopoulus [10] analyzes contemporary trends in the development of scientific methodology. Actually, the problem of applying positivism approaches is presented in the works of M. Major [11], where positivism is seen as a set of universal approaches to the verification of economic information. C. Clarke [9] considers positivism as a general scientific methodology that can be applied to economic research. In general, all authors point to several trends. Due to the appearance of an unprecedented large amount of economic information (bigdata), the issue of its processing and interpretation is newly raised. Also, due to the high degree of branching of economic disciplines, conducting of interdisciplinary researches, it became problematic to compare the content of the divergent directions, to compare individual scientific works.

Presentation of the main research material. In the scientific economic literature, there is a relative consensus 
about what to consider positivism in the economy: it is such a vision of economic realities, which is based on accurate data on the object of research (that is, those that can be proved, checked), and which can be expressed in monetary terms measurement (in one way or another). Positivism in economic discipline is not identical to philosophical positivism as such (as well as its trends), but it is connected with it in methodological and lexical communication [1, p. 175].

If the question is even narrower and only the economic theory is considered, then positivism is a counterweight to normativism: according to its regulations, the source of economic knowledge should be empirical research, and the discovery of objective laws of economic development is the main objective of any economic research. Abstract theoretical constructs, thinking about "as it should be" (which is characteristic of normativism) from the standpoint of positivism it doesn't have meaning or value. The reality is one: everything is the way it should be. However, positivism is criticized a lot in economic theory: positivism is considered to be more rhetoric in the economic scholarly dispute than the methodological basis for the research apparatus. This point of view is based on the fact that in today's economic theory there is such a diversity of scientific approaches that the boundary between "what is now" and "what should be" is very conditional. Thus, among economists researchers, it is permissible to ignore the results of empirical research if they do not find confirmation in theoretical models (deviations from the theory are attributed to poor government or subjective market factors, speculations, political influence on the economy, etc.).

In short, it is impossible to say what today's economic theory looks like. The number of paradigms, theories, hypotheses and ideological currents is very large. However, it can be argued that over the last few decades in the economic theory there is a struggle between the representatives of the two largest scientific schools: economics and political economy. Representatives of "economics" are associated mainly with the American economic school, political economy - with the European one, but today territorial differences have given way to differences in views. The science school "Economics", which is currently expanding into an entire system of theories and scientific approaches, involves studying the macroeconomic situation, supply and demand, competition, market behavior. The success of economic policy, which is identified with the economics scholarly school in 1990-2000, the economic dominance of the United States has increased the credibility of this scientific direction, although critical views on it are now more popular. Critics blame the "economics" in isolation from the realities of the economy, exaggerating the values of abstract models, as well as the fragmentation of the description of reality. The lack of a holistic, complete, credible look at the economic system is its main disadvantage. Now, when it is available for researchers to study large amounts of data, a developed statistical apparatus is available, as well as unprecedented computing power, an excessive mathematization of economic science creates an illusion of the reliability of its results. That is, the very fact of active use in the study of a mathematical apparatus is often perceived as proof of the data reliability. By the way, this effect - excessive (often groundless) mathematization of research - is actively spreading to other humanitarian disciplines. That is, the following criterion for the truth of the results of scientific research is deleted: "The degree of reliability, truthfulness and value of the data obtained in scientific and economic research is identical to the degree of application of the mathematical apparatus." In other words, we have a tendency to technologize science, when scientific research, creative approach to the problem and deep understanding of the essence of the object under study are replaced by a set of technological techniques [4, p. 10].

Partially this approach justified itself in the areas where it is possible to fully describe the investigated object (phenomenon) in one array of data, that is, to digitize $100 \%$. This is the facility for the use of all available statistical apparatus. Such an approach can be found in such spheres as trade in commodity, currency and stock exchanges. But even under such conditions, the approach of the scientific school "economics" gives a satisfactory result only during small periods of time, which do not suffer from major systemic crises. As practice has shown, a deep crisis with the help of the entire econometric apparatus cannot be foreseen. Moreover, it is impossible to conduct a qualitative analysis of the situation, to find a way out of the crisis. The global economic crisis of 2008 caused a huge damage to the reputation of "economics" and its apparatus both in society and in the scientific community. In the period before the global economic crisis, all major players in the world market were "armed" with mathematical models, risk management practices. From the standpoint of "economics" they were completely protected, and were out of the risk area. Nevertheless, practice has shown that the most authoritative institutions (rating agencies, for example) turned out to be helpless, their estimates and forecasts were false.

Nevertheless, the approach to economic research, which is practiced "economics" - digitalization of the object of research and the large-scale use of mathematical apparatus deeply entered the economic science [3, p. 8].

Incidentally, such processes occur not only in economic science and related disciplines, but also in other fields of knowledge, areas of creative and intellectual activity. For example, if you consider the system of higher education (in particular, higher economic education), students are simply invited to study a certain amount of information and algorithms of action that they should master and learn to reproduce.

In addition to the norm about the need to use a mathematical apparatus in the study, within the framework of "economics" a certain ideological base was formed, according to which reliable economic studies are considered only those that are performed only within certain scientific categories, concepts and lexis. Such "framework" concepts are: lack of an alternative to private property as the basis of economic development and household incomes, undeniable will of entrepreneurship and the will of a personal choice, personal interest of the person as the main driver of entrepreneurship, free competition, market relations and market self-regulation along with the limited role of the state. The very same economic science is defined as "social science, which explores the problems of the effective use of limited resources in order to maximize the satisfaction of material needs of man" [2, p. 88]. 
It prevents the formation of an effective methodology of search in economic research and an informal "directive" from society for a fast result, which can be expressed in monetary terms. That is, there is the process of identification of the effectiveness of scientific research and the truthfulness of the results with a potential commercial effect. Figuratively speaking, society (in the broadest sense) expects from scholars a recipe of how to become richer. In part, this position is correct. And it is easy to understand the reason for such expectations. But the task of economic science is not restricted to this. However, society's expectations have very deep implications and versatile manifestations. This phenomenon can be called "academic capitalism". It emerged in economics, which explores highly capitalized spheres of the economy - banking, stock markets, and spread to the rest of the economic disciplines.

An important place in the assessment of the truth of scientific results, as well as knowledge in the broadest sense, is the widespread concept of the "knowledge economy". On the one hand, the emergence of this concept, from the standpoint of which the greatest value produced by the economic system is knowledge. You can agree with this. But on the other hand, the question arises of assessing this knowledge, assessing the growth of such "knowledge economy". So there is a request for a reassessment of scientific results (it is the basics of any new knowledge) on a commercial basis. In some cases, this can be realized. That is why we have development of the direction of the economy, which deals with intellectual property. According to it, the effectiveness of scientific research is equated with the value of the patent, which protects the object of intellectual property, which is the result of this study. To some extent the approach is quite convenient: in many scientific fields (especially those in which laboratory research is used), during the research and development, the final result is a certain development (material, substance) that can be sold. Especially, if we are talking about a study that is aimed exclusively at solving a particular practical problem. But for the most part, such a commercial approach to the evaluation of the scientific performance results only in the hyperbolisation of monetary valuation [7, p. 70].

That is, we can say about "economism" in the economy as an analogue of positivism. However, as an empirical confirmation in "economism" a fairly limited research apparatus is used, where too much importance is attached to the mathematical methods and ideological and theoretical positions of the liberal economy.

In the context of the interpretation of positivism in economic science, one should pay attention to another very important trend that has embraced the entire scientific sphere: the absolute value of bibliometric indicators. The articles cited by the WebofScience and Scopus databases were introduced to facilitate the statistical analysis of scientific results, the alignment to one standard scientific reporting, and the ease of navigation among previously published articles. But for the time being, this approach (bibliometrics) has spread to such a scale that it has become a criterion of truth to be replaced. That is, the fact of publication of an article in a magazine with a high Impact factor is accepted as a recognition of the value, authenticity and scientific significance of the published material (although, in fact, it only reflects the subjective assessment of the editorial board of the magazine). But the value of bibliometrics to assess the reliability of scientific results is so great that one can speak of a separate, specific kind of positivism in economic science - "bibliometrics" [1, p. 185].

Discussion around bibliometric indicators is quite continuous and complicated. With a number of advantages and benefits that are contained in bibliometrics as a method of generalized analysis of the effectiveness of research, it can be said that now there is the hyperbolisation of such indicators. And not in the understanding of the assessment of the contribution and level of qualification of the individual scientist (this is where the bibliometric works well), but in understanding of the substitution of the biometric objective criteria of truth.

Skeptics say that this approach is a pull-out of the context of the tools of bibliometrics and their application is for "the assessment of everything." In fact, the numerical strengths of bibliometrics create the illusion that this toolkit can solve all the critical issues of scientific evaluation. But with the help of bibliometric indicators it is impossible to evaluate the creation of new theories, scientific breakthroughs, advancement of revolutionary scientific ideas [8].

The desire of the authorities, the private sector and (partly) society to "corporatize" the scientific sphere, equating it with other areas of economic activity, is prompted by increased demand for bibliographic indicators. This distorts the perception of society by science, research, and, in the end, the meaningful devastation of scientific research. Indeed, in order to have a high ranking of citations, it is not necessary to have great scientific achievements. Just as not every scientific result can find a response in the scientific community. In the end, the misuse of bibliometrics significantly disorientes the scientific community.

The penetration of bibliometrics into the scientific community, the dissemination of "bibliometrics" as the fundamental criterion of value and the truth of the scientific result completely rebuilds the perception of the scientific community. There is a "cult of numbers" when a scientific search of both individual scientists and entire groups is directed only at those areas and scientific problems, the publications on which have the highest chances to be cited. Skeptics even say the general tendency that managers who care for the scientific sphere are under the "hypnotic action of bibliometrics" and believe in its "magic power". If we talk about economic science, then under such conditions, scientific research is to "hunt for fresh and original statistical data", and their conduct of the standard (according to a stable algorithm) statistical analysis and complete neglect of qualitative analysis [1, c .188].

The adoption of the principle of "bibliometrics" as the main in determining the value and reliability of scientific research leads to a number of negative consequences. Thus, the structure and new knowledge are "simplified" and the motivation for completely original research is lost. Because every scientist is involved in the quest for citation, all topics that have no chance of being quoted are left out of his attention. Instead of a complex and multifaceted scientific picture of the world, we receive a series 
of ratings and "line-ranked" articles - from the most cited to the least cited.

Further - more: strengthening the public request for the reform of science, transferring it to the generally accepted in the public administration or business organizational framework sharply raises the question of a universal instrument for measuring the effectiveness of science and the effectiveness of the scientist. It is here that the instrument of bibliometrics falls to the point. Thus the position of "bibliometrics" is strengthened, and these changes are followed even at the level of human communication of scientists and their mutual perception. Instead of discussing substantially new publications, and the essence of the contribution to the science of each of the colleagues, the quotation level is subject to discussion. But the formation of science and its development - this is not a chain of people with the highest level of citation: it is a story of changing views, the emergence of ideas, proof and refutation, original experiments, scientific research [2, p. 87].

Consequently, the adoption of the principle of "bibliometrics" in economic science as one of the manifestations of "positivism" has several consequences. On the one hand, society (and the state) receives a clear structure for scientific sphere and scientific knowledge. The results of scientific studies are relatively easy to measure and substitute. But, in essence, there is a substitution of concepts: instead of focusing on new knowledge, the scientist (or team of researchers) focuses on obtaining results that will be well cited. Cognition, as the main objective of research, is replaced by efficiency and productivity. It means that the funds are allocated by the society to the scientific sphere (through public or private institutions) for the scientists not to advance in knowledge of the surrounding world, but to make them more effective. Such a model works only when it comes to applied tasks, or about the most common problems, the essence of which is understandable to a middle-educated person. But this model is helpless for solving complex scientific problems.

Conclusions received from the research. Due to a number of reasons (increasing the volume of information, complicating the structure of economic science etc.), the issue of verification of the results of economic research and evaluation of their quality and reliability have become relevant. Economic policy, the practice of applying the results of economic science has shown that quite often the scientific provisions are separated from life, and the constructed economic models do not reflect reality. Moreover, the failure, with the help of a modern mathematical apparatus, to make credible forecasts of economic development raised the question of the usefulness of economic science in general. In this situation the scientific community began to debate about the development of the methodological component of science, its evidence base. In view of this, the philosophy of positivism is a rather popular direction among scientists engaged in methodological problems of economic science. However, positivism in the economy has a slightly different meaning, rather than purely philosophical positivism: it is reduced to the priority of empirical data over theoretical constructions. However, the spread of the ideas of positivism in economic science has several negative manifestations: the establishment of "economism" and "bibliometrics". "Economism" is to exaggerate the value of mathematical and statistical substitution concepts. Instead of the effectiveness of scientific research, they speak of the efficiency and productivity of the scientific sphere. The significance of scientific information has been replaced by a subjective assessment of the scientific community. Another manifestation of "positivism" in the economy is "bibliometrics", excessive use of bibliometrics tools to assess the effectiveness and significance of scientific research. A request from the society on a simple and clear structure of the scientific sphere and a universal assessment of scientific activity led to the fact that bibliometrics became the main method for determining the significance of scientific work, the scientist, the importance of scientific direction. In general, despite the apparent need for further development of the scientific methodology of economic science in the part of the evidentiary apparatus, there is a substitution of concepts. The principles of positivism, which are mostly declared, are replaced by excessive use of mathematical apparatus, subjective evaluation and the use of bibliometrics as a universal method for evaluating scientific results.

\section{REFERENCES}

1. Алексеев, А.П., Алексеева И.Ю. (2015). Экономический позитивизм и будущее науки.Философия науки и техники,20(1)

2. Андрійчук В.Г. (2016). Сутнісний аспект методології наукових досліджень.Економіка АПК, (7), 87-94.

3. Геєць В. (2015). Політико-економічні засади дослідження сучасного суспільства.Економічна теорія, (3), 5-13.

4. Довбенко М. (2017). Економічна теорія початку XXI століття: криза чи розвиток?Журнал європейської економіки,9(1), 3-18.

5. Єфименко, Т.І., Леоненко, П. М. (2015). Методологічний фундамент економічних поглядів МI ТуганаБарановського (до 150-річчя від дня народження).Фінанси України, (4), 7-33.

6. Мельник, А., Ціщик, Н. (2017). Сектор домогосподарств у сучасній економічній системі: теоретичні та емпіричні

аспекти.Вісник Тернопільського національного економічного університету, (3), 7-21.

7. Шумська, С.С. (2017). Гроші та економічна динаміка в Україні: теорія та емпіричні оцінки взаємозв'язку.Економіка та суспільство, 63

8. Boland L.A. (2014).The Methodology of Economic Model Building (Routledge Revivals): Methodology After Samuelson. Routledge.

9. Clarke C. (2016). Preferences and Positivist Methodology in Economics.Philosophy of Science,83(2), 192-212.

10. Drakopoulos, S., Katselidis, I. (2014). The development of trade union theory and mainstream economic methodology.Journal of Economic Issues,48(4), 1133-1149.

11. Major M.J. (2017). Positivism and "alternative" accounting research.Revista Contabilidade \& Finanças,28(74), 173-178. 